Published on Reviews in History (https://reviews.history.ac.uk)

\title{
War: An Enquiry
}

Review Number: 2206

Publish date: Thursday, 7 December, 2017

Author: A. C. Grayling

ISBN: 9780300175349

Date of Publication: 2017

Price: $£ 18.95$

Pages: 288pp.

Publisher: Yale University Press

Publisher url: https://yalebooks.yale.edu/book/9780300175349/war

Place of Publication: Yale, NH

Reviewer: James G. R. Cronin

Media, with alarming regularity, reports nuclear threats from North Korea and President Trump's rhetorical belligerency; Russian and Chinese irredentism conflicts in the Middle East and Afghanistan, across the Sahel region of Africa and Yemen; not to forget the asymmentry of terrorism. Is there any consolation to be had in philosophy for the cultural phenomenon of war? Anthony Clifford Grayling's War: An Enquiry makes penetrating and provocative reading. He defines war as 'a state of armed conflict between states or nations, or between identified and organised groups of significant size or character' (p. 9). Grayling, British philosopher and public intellectual, in this humanistic enquiry, asks: why have humans made war for the past 10,000 years of history and what can be done to mitigate, if not eliminate, its suffering?

This review will focus on A. C. Grayling's assertion that war is synonoymous with the ascent of civilisation. Grayling's reasoned enquiry surveys the causes of war, its effects and attempts to limit warfare. This approach is appropriate for interrogating connections between war and civilisation as the collective cultural enterprise to moblised political communities for warfare. In this, Grayling is revisiting philosophical ground he previously covered in Among the Dead Cities in which he highlighted the difficulties of maintaining moral restraint during wartime as illustrated by his philosophical enquiry into the indiscriminate allied bombing of German and Japanese cities during the Second World War.(1) The controversy surrounding Among the Dead Cities is indicative of normative cultural constructions, principally commitment to tribal nationalism, that have enabled the legitimacy of war as a means to political ends.(2)

The first part of A. C. Grayling's enquiry into war focuses on the function of the state apparatus that had the power to command organisational capacity to make war, which distinguishes war from indiscriminate violence. The focus of the first part is on connections between technology and tactics and how these have effected the evolution of warfare as part of the political organisation required to support and sustain it. Grayling's chapter on ancient warfare focuses on the Bronze and Iron Age from the Sumerian city-states to the Roman Empire. Grayling draws on the scholarship of Harry Holbert Turney-High, an American anthropologist and sociologist (pp. 19-23). Societies approached what Turney-High called the military horizon - the point at which war becomes civilised - only to the extent that they mastered social regimentation, discipline and tactics. 
A. C. Grayling's broad sweep from medieval to modern warfare surveys how technology changed both tactics and military organisation. Recent scholarship argues that modern warfare was rooted in the Enlightenment project of the 18th century with the hope that the methods of scientific enquiry could make war more exact, predicatable and, as a consequence, winnable, if its general principles could be identified and applied (p. 83). The transition from medieval to modern conceptions of warfare is highlighted by Grayling's awareness that just as the European Renaissance was mining classical literature to inform its military thinking, so the development of gunpowder weapons was undermining the utility of using these classical principles. During the 18th century, the formation of standing armies marked a movement towards a professional military establishment and the emergence of a bureaucracy that was necessary for supporting its organisational structure through logistics of supply and transport that led to the greater organisation of military life (pp. 76-7). Grayling focuses on three movements that have shaped modern warfare: total war, aeral bombardment, and containment. His emphasis on the psychology of motivation as a German Romantic rejection of the rationality of the Englishment is exemplified by the Prussian military theorist, Carl von Clausewitz, who rejected the Enlightenment's proposal that there were universal principles of war. The reality of war, Grayling claims of Clausewitz, cannot be reduced to rules (p. 87). In Germany, Clausewitz became the dominant theorist because of his connection with Prussian-German militarism that led to the First World War and which placed emphasis on the value of 'total war' for the destruction of the enemy (pp. 90-3). That doctrine was associated with Clausewitz, whose theories Sir Basil Liddell Hart blamed for the horrors of the First World War (p. 108). It was the effect of the First World War that gave the first impetus to a determination to avoid the attritional stalemate of static trench warfare, and to reject the 19th-century belief in all-out war, aimed at achieving swift victory in decisive battle by a nation at arms employing the tactic of massed attack. Grayling is on firm ground as he attributes the genesis of the tactics of aerial bombing to the writing of Giulio Douhet whose manual from 1921 on the potential role of such bombardments was to influence RAF Bomber Command during the Second World War. The civilian population was targeted by an enemy in order to force its government to seek peace (pp. 94-5). This was scholarly ground that Grayling expertly covered in Among the Dead Cities through his discussion of the rationale for bombing German and Japanese cities during the Second World War. Containment, a theory of limited war and one of economic attrition rather than battlefield attrition (p. 112) was a characteristic of the Cold War (1947-91). It continues to be used through the imposition of sanctions on hostile states in efforts to limit their capacity to prepare for war.

In part two, A. C. Grayling questions whether the causes of war can be ascribed to the psychology of human predelection (in which case war is inevitable) or to social organisation (which gives us a way out) (p. 118). His surveying of the biological and psychological causes of war covers work previously examined by American psychiatrist Jerome D. Frank at the height of the Cold War.(3) Frank gave more intellectual consideration to to non-violent action as a constructive alternative to war, than does Grayling. Here, Grayling's reticence can be explained by the fact that Frank's alternative formed part of the discourse of the transatlantic anti-nuclear movement that contributed to grassroots lobbying to end atmospheric nuclear testing with ratification of the Partial Test Ban Treaty in 1963 as the first significant agreement of the nuclear age. Grayling argues that while war may be violent and the expression of individuals, nevertheless, the organisation of war requires a collective expression and collective effort which is best done calmly and without violence, so there is a direct correlation in his thinking between organisation and war-making (p. 121). This implies that war is a direct outgrowth of the political, economic and cultural arrangements that evolved when settled societies emerged into history about 10,000 years ago (p. 160). In this sense, Grayling opposes the tribalism of nationalism and seeks to promote international cooperation and understanding as a way of preventing war, to see the other as a version of ourselves (p. 161).

In discussing the causes of war Grayling uses the framework of causation by the political scientist Kenneth Waltz: the individual, the state and the international order (p. 142). Grayling identifies tensions between the person as a subject in contrast to the individual as a utilitarian object. Psychologically, to engage in war requires the objectification of the enemy as the 'other', which reduces personhood and allows for the development of pro-war propaganda making the process of going to war easier. Grayling's analysis of 
political realism as the dominant mode of looking at international relations since 1945 highlights the prominence of a pessimistic intellectual outlook concerning alternatives to war. Realism argues that states are anarchic and act from positions of self-interest rather than altruism.

Grayling considers the ethical dilemma that has been an ongoing concern of moral philosophers throughout the centuries. This dilemma is whether the positive effects of war - technological and social advances, the liberation of suppressed populations, the defeat of regimes - compensate for its negative effects - the destruction of material and cultural artefacts as well as individual suffering (p. 183). The third part of Grayling's enquiry focuses on attempts to limit war. Here, Grayling has his eyes firmly fixed on the effects of war in the Middle East as this has created a culture of fear in the West. Grayling acknowledges that the realist justification of self defence by pre-emption is an ethical fig-leaf. Grayling is critical of the principles of just war ethics as being incompatible with the promotion of justice due to the destructive effects of modern warfare. He argues this with reference to Michael Walzer and the destruction caused by nuclear weapons during the Cold War (p. 200). Grayling also views religion negatively (p. 127). Grayling argues that Christian thought concerning just war was not only a product of charitable efforts to mitigate the horrors of war, but was also an effort to justify war despite the fact that Christianity is manifestly a non-violent pacifist religion (p. 189). The reviewer does not dismiss Grayling's view, but would counter his argument by proposing that Grayling's stance is merely one dimension of a more complex interplay regarding the nature of religion as a force for moral persuasion. Religious influence in the public sphere has been motivated by altruism based on the espousal of the dignity of the person. Christian moral philosophy, for example, has always been concerned with the question of whether justice can be an outcome of warfare. The evolution of just war was a search for restraint, made necessary by the fact that the Church tried to reconcile the belligerency of the Old Testament with the pacifism of the New Testament. During the 20th century there have been concerted efforts by moral philosophers to review the premises of just war ethics in the face of increasing threats posed by modern warfare.

Grayling argues for the primacy of the humanitarian dimension in war-making. He argues that humanitarian law as law marks an implicit admission that moral adjuration by itself will always be insufficient to stay the slayer's hand. Grayling, in his analysis, favours law because it has the power of enforcement, whereas, morality is merely a troubled conscience (p. 213). However, this is dismissive of the soft power of morality in political persuasion and education, as manifested by the activism of pacifist religious groups throughout history. The distinction Grayling makes between morality and legalism does not neatly align with the historical evidence. For example, Vatican Ostpolitik (1958-78) had the intention of improving East-West relations through dialogue between the Vatican and Moscow during the height of the Cold War. This policy was equally informed by the emergence of rights discourse with the ratification of the Universal Declaration of Human Rights (UDHR), drafted in 1947 and ratified in 1948, with the non-violent ethos of the Christian gospel. $(4)$

Grayling's historical enquiry touches the concerns of critics who argue that there can be no moral bystanders in modern wars. Populations are complicit in the collective enterprise of state militarism. Cultural geographer Derek Gregory has described the systematic abstraction needed to generate a military target as a 'kill chain' that acknowledges the 'complicity of the public in the destruction'.(5) Philosopher Grégoire Chamayou reiterates this argument in his study of the philosophy of drone deployments by the United States in the Middle East and Afghanistan. Military drones, deployed to hold international terrorism at bay, also expose inherent vulnerabilities of the deploying state to surprise attack. Which, in turn, provokes a counter response that endangers the civil liberties that state security seeks to defend. $\underline{(6)}$

A. C. Grayling concludes with a modicum of hope by arguing that war is a product of culture. If we want to eliminate war then we need to reflect on our political and cultural systems. Grayling argues that war is a product of political organisation rather than human nature (p. 230). It is this cultural context that makes us all participants and complicit and responsible for the elimination of war, as war is produced by government contracts and honouring the military. The answer is to dDeinstitutionalise war, stop romanticising it, and stop censoring the truth about it (p. 232). Grayling ends his enquiry by arguing that the promotion of social 
justice would contribute to the end of war. In this respect, he takes a humanitarian view of war. Grayling's examination of the pathology of war as synonymous with civilisation challenges his readers to question the extent to which we are all complicit in this collective enterprise.

\section{Notes}

1. Anthony C. Grayling, Among the Dead Cities: Is the Targeting of Civilians in War Ever Justified? (London, 2006).Back to (1)

2. Timothy P. Jackson, Political Agape: Christian Love and Liberal Democracy (Emory University Studies in Law and Religion) (Grand Rapids, MI, 2015), p. 8.Back to (2)

3. Jerome D. Frank, Sanity and Survival: Psychological Aspects of War and Peace. (New York, NY, 1967). Back to (3)

4. Jonathan Luxmoore and Jolanta Babiuch, The Vatican and the Red Flag: The Struggle for the Soul of Eastern Europe. (London, 1999), 112-13.Back to (4)

5. Derek Gregory, "'Doors into Nowhere": dead cities and the natural history of destruction', Cultural Memories, Knowledge and Space 4, ed. P. Meusburger et al. (Berlin, 2011), p. 158.Back to (5)

6. Grégoire Chamayou, Drone Theory. (London, 2015). Back to (6)

Source URL:https://reviews.history.ac.uk/review/2206

\section{Links}

[1] https://reviews.history.ac.uk/item/274275 